\title{
Review on the Fate of Contaminants in the Niger Delta Environment
}

\author{
Ogunkeyede Akinyemi Olufemi* Nwokolo Ijeoma Jacinta Ossai Andrew \\ Igwemoh Uyemhe Rosemary Paul Akpejeluh \\ The Department of Environmental Management and Toxicology, Federal University of Petroleum Resources, \\ Effurun, Delta State, Nigeria
}

\begin{abstract}
Niger Delta environment had suffered from impacts of waste over the years. The significant wastes in the region are crude oil and municipal wastes. Studies have shown the effect and fate of contaminants in the environment and human life. This paper reviews the impact and fate of contaminants in the Niger Delta environment with the focus on crude oil waste and municipal waste. The substantial quantities of waste generated resulted from unreasonable consumption and production, non-compliance to environmental laws and regulations, migration to urban cities, and sporadic expansion of unregulated industrial operations. These contaminants affect various life forms, natural resources, and increase the rate of global warming. It is of urgent importance for concerted efforts from corporate bodies, government, and individuals to ensure proper implementation of effective, safe management of waste. This review used Niger Delta environmental contaminant analysis and remediation case studies to highlight the fate of organic and inorganic contaminants and their associated adverse effects on the environment. This review contains secondary data from online journal articles, radio, symposium, doctoral thesis, organisations, and websites.

Keywords: Crude oil, Heavy hydrocarbons, Spills, Dumpsite, Pesticides, Fate, contaminants, Toxic, Degradation. DOI: $10.7176 / \mathrm{JEES} / 10-5-05$

Publication date:May $31^{\text {st }} 2020$

\section{INTRODUCTION}

Contaminants are materials or substances that have adverse impacts on the environment. The nature of the contaminants could be a biological, chemical, physical, or radiological substance, which in sufficient concentration, can affect living organisms through the air, water, soil, and food. New Hampshire Department of environmental services (2009) defines organic contaminants as carbon-based chemicals introduced into the environment through natural or human activities. Inorganic contaminants in the same vein could occur through natural and anthropogenic processes. Potential sources of organic and inorganic contaminants include industrial leaks and spills, leaks from oil and chemical storage tanks, improper application of pesticides, careless disposal of cleaners, oil, and antifreeze, improper disposal of household wastes, landfills and garbage dumps, leaks from a pipeline, and accidents or spills during transportation (Florida Department of Environmental Protection, 2019; New Hampshire Department of environmental services, 2009). Figure 1 shows leakage from an underground tank. Non-aqueous phase liquids (NAPLs) like petroleum hydrocarbons contaminate groundwater through spills during transportation and leakage from underground storage tanks.

Figure 1 revealed the contaminants released from a specified area like a landfill site, chemicals from industrial pipes or leaking pipelines as point source contamination, while the released over a spread area from agriculture, from air into water, contaminated sediments are diffuse or nonpoint source contamination (Moustafa et al., 2016; Environment Protection Authority Victoria, 2018). Discontinued industrial discharges or one-time spills often live in sediments and release pollutants into the water column. Metals and deposits of salt that leach into groundwater are some natural sources of contaminants. The contamination source is a factor that determines the distribution and concentration of contaminants.

Niger Delta is the largest wetland in Africa and the home to mangrove swamps, rainforest, and freshwater swamps (Wetlands international, 2016). The Delta region has critical environmental issues because of the spillages associated with oil exploration within the nine states as reported that between 9 million and 13 million barrels spilt in the Niger Delta since 1958 (Baird, 2010). Oil spills occur because of accidents by tankers, during production, old infrastructures, and sabotage. Lack of inspection and maintenance of old infrastructures lead to corrosion, rupturing, and leakage (Nwilo and Badejo, 2001).
\end{abstract}




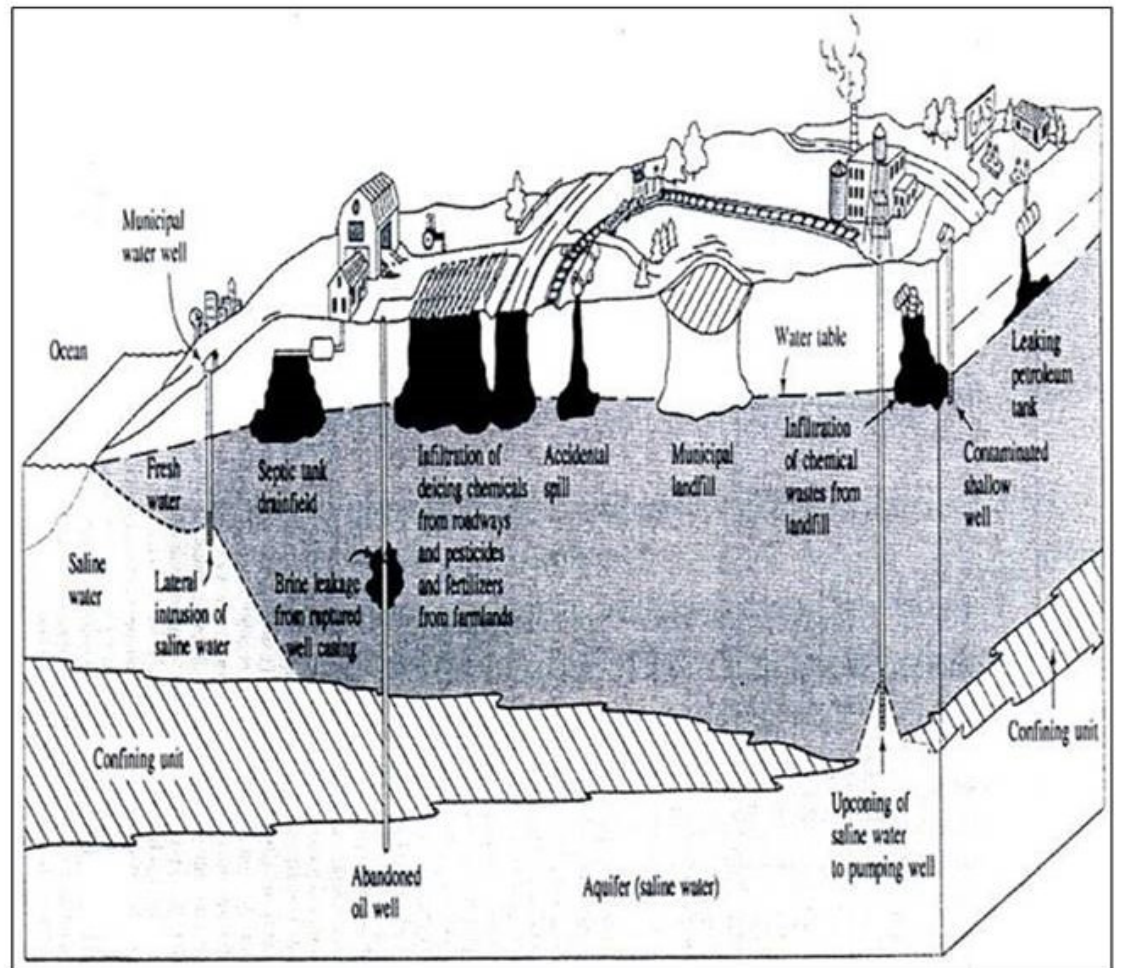

Figure 1:Groundwater and Soil Contamination SourcesSource: (Moustafa et al., 2016)

Pipelines are left to function above their lifespan of about fifteen years (Bronwen Manby, 1999). Shell Petroleum and Development Company stated that facilities would not be constructed today, like in the 1960s (Shell, 1995). Sabotage and theft through oil siphoning is a significant issue in the Niger River Delta states, contributing to further environmental degradation (Anderson, 2005). The repair of broken lines takes long. Saboteurs sell oil on the black market (Bronwen Manby, 1999). The oil industry self regulates because of weak and enforced regulations (Baird, 2010). Natural gas flaring reduces the cost associated with separating it from oil. Toxic constituents from gas flaring pollute the atmosphere and cause climate change. Large amounts of carbon dioxide $\left(\mathrm{CO}_{2}\right)$, and methane are released from gas flaring, causing global warming. These gas can be re-injected into the ground or stored as an energy source. The toxic effects of petroleum contamination on the Niger Delta environment have led to the loss of livelihoods, depletion of natural resources, health issues, and loss of life.

Municipal solid waste is another issue in Niger Delta. High population and little facilities for handling of waste lead to environmental pollution. Toxic leachates from dumpsite are transformed biologically or chemically and transported through air or runoff to contaminate the soil or water (Kola-Olusanya, 2012). The burning of waste generates toxic gases (Okeke, 2014) and causes environmental and health issues (Ayuba et al., 2013; Adekunle et al., 2011; Jalil, 2010). Open dump, in situ burning, and landfill, which causes environmental pollution, is the most common method of waste disposal in Niger delta (Onwughara et al., 2010).

This reviewed paper discussed the fate of contaminants in the Niger Delta, as it is vital for risk assessment and determines the exposure of an ecological receptor to the contaminants (McMillen et al., 2001). This review used empirical data to analyse the fate of organic and inorganic contaminants in the Niger Delta. Sources of secondary data for the study include journal articles within and outside Nigeria, websites, environmental bodies, organisations, symposiums, doctoral thesis submission, and radio. Data analysed for the study include socioeconomic characteristics of Niger Delta, farmer's livelihood, contamination of the environment, and productivity. The analytical method used includes descriptive and inferential statistics.

\section{BEHAVIOUR AND FATE OF HEAVY HYDROCARBONS}

The concentration and potential exposure are essential to gain data on hydrocarbon distribution and behaviour (Coulon et al., 2010). Transport and transformation processes of hydrocarbons include the surface release of crude oil and infiltration into the unsaturated zone, non-aqueous phase liquid (NAPL) body partitioning near the water table, Increase in proportion of heavy hydrocarbons because of attenuation of oil, and removal of heavy hydrocarbons by biodegradation. Experts can predict the highest risk of hydrocarbon exposure to human health and the environment from its transport and transformation stages.

Spillage of crude oil in sufficient quantity enables its entrance into the soil subsurface to form the NAPL body at the water table. Soil properties (moisture, pore size, porosity, density, viscosity, surface tension) determines the extent and rate of infiltration. When soil permeability is high, and crude viscosity is low, the degree and frequency 
of soil penetration by crude will be more (Keller \& Simmons 2005; Brost \& DeVaull 2000; API 1972). When crude oil penetrates the soil to where the NAPL head cannot overcome pore pressures of entry, migration stops. Cessation of crude oil migration is because of capillary forces in the soil column, which leaves behind immobile NAPL. The saturated zone in the soil undergoes various hydrocarbon attenuation and transport processes (Bear \& Cheng 2010; McCarty \& Ellis 2002). Researchers revealed that hydrocarbons' migration towards the water table does not occur when they are present in the soil at low concentrations. In $99 \%$ of various oil dose at $2 \%$ (w/w) mixed into the top $15 \mathrm{~cm}$ of different soil (silty loam, sandy loam, and black clay loam) stayed within $20 \mathrm{~cm}$ of the surface after one year (Raymond et al.,1976). Brost \& DeVaull, (2000) discovered that a range of heavy petroleum products had different soil residual saturation points of $0.5-15 \%(\mathrm{w} / \mathrm{w})$, with lower values observed in coarse soils.

When hydrocarbon exceeds its residual soil saturation point, NAPL goes through the soil to the water column. The hydrocarbons dissolve and generate contaminants that transfer to receptors. Pollard et al. (2008) developed level 1 fugacity models that show the partitioning behaviour in water, NAPL, air, and soil systems. Hydrocarbons show a tendency for partitioning into soil and NAPL than air, and water, which means the limited transfer of heavy hydrocarbon into groundwater. Nham et al. (2015) stated that further transport of dissolved hydrocarbons in groundwater is estimated using retardation factors. McMillen et al. (2001) proposed physical and chemical properties that aided the estimation of hydrocarbon retardation factor. The retardation factor of heavy hydrocarbon is very high, resulting in limited transport in groundwater after dissolution. An exception to this position is karstic geological environments where NAPL is transferred over distance. Schwarz et al. (2011) state that an unacceptable impact of karstic transport of heavy hydrocarbons to groundwater is low, which limits the interest of heavy hydrocarbon in hydrogeological risk assessment. Heavy hydrocarbons consideration is essential in risk management of soils or free-floating NAPLs to control exposure points. Coulon et al. (2010) proposed a level 11 fugacity model, which shows that biodegradation effectiveness determines the ultimate heavy hydrocarbons fate. Photooxidation also aids in the mass removal of heavy hydrocarbons.

Photooxidation transforms oil spill components at the soil surface by exposure to sunlight. Molecules within the crude oil mixture absorb photons, which start oxidation reactions by radial chain oxidation and singlet oxygen (Shankar et al., 2015). Lee 2003 and Maki et al. (2001) said this oxidation reaction of crude oil molecules in an increase of oxygenated hydrocarbons more susceptible to biodegradation. Garrett et al. (1998) proposed the transformation of oxygenated high molecular weight aromatic hydrocarbons by photooxidation. (Prince et al., 2003), and co-workers showed increasing levels of photooxidation with increasing aromaticity and alkylation of Polycyclic aromatic hydrocarbons (PAHs). Prince et al. (2003) state that asphaltenes or resins are not subject to significant photo-oxidative destruction. Photooxidation will be effective only at the soil surface since it requires direct sunlight. Braddock et al. (2003) revealed that reduced removal rates of crude oil over 25 years in soil horizons ( $>8 \mathrm{~cm}$ from the surface) at an Alaskan test site is because of no photooxidation caused by low sunlight penetration. There should be a future investigation on the outcome of soil turning in photooxidation. There are many published studies on hydrocarbon biodegradation; however, light hydrocarbons had more reviews than heavy hydrocarbon degradation (Abbasian et al., 2015; Seo et al., 2009; Widdel \& Rabus, 2001; Boonchan et al., 2000; Cerniglia, 1992; Leahy \& Colwell, 1990; Atlas, 1981). Throne-Holst et al. (2007) stated a novel monooxygenase from Acinetobacter in biodegradation of heavy hydrocarbons, while there are multiple known enzymes for light hydrocarbon degradation. In laboratory studies, Sakai et al., (1994) showed biodegradation of heavy hydrocarbon like long-chain $n$-alkanes under aerobic conditions. Studies showed asphaltenes and resins degradation to varying degrees under aerobic and anaerobic conditions (Meslé et al., 2013; Furmann et al., 2013; Tabatabaee et al., 2012; Singh et al., 2012; Uribe-Alvarez et al., 2011; Strąpoć et al., 2008; Kim et al., 2005). Heavy hydrocarbons are susceptible to biodegradation. Gibb's free energy calculations show that potential energy available through biodegradation is only affected by hydrocarbon size under most redox conditions. Laboratory conditions do not reflect field observations. Field studies showed limited heavy hydrocarbon biodegradation. Complete removal of heavy hydrocarbon is often unachievable (Raymond et al., 1976; Francke \& Clark 1974; Kincannon 1972).

In hydrocarbons subjected to aerobic conditions, heavy hydrocarbon residue remains after the removal of light hydrocarbon (Huesemann, 1995), after a year of land farming, detected about at least 75\% of heavy aromatics, and about 30\% heavy saturates remained from a range of crude oils and petroleum products. Loehr et al. (1992) showed $(20-24 \%)$ of an oily sludge remained after two years of land treatment. Salanitro et al. (1997) tested the extent of hydrocarbon biodegradation in soils containing different American Petroleum Institute (API) gravity (14, 30 , and 55) of crude oil and observed a fraction after 11 months of treatment. Biodegradation occurred in only $6-$ $44 \%$ of heavy hydrocarbon during the experiment. Soils with higher organic carbon showed least oil biodegradation. McMillen et al. (2001) showed that heavy hydrocarbon determines the final extent of oil removal from soils. Grishchenkov et al. (2000) showed that heavy hydrocarbon biodegradation in the subsurface anaerobic condition is limited than in surface soil. Reddy et al. (2002) showed evidence of little biodegradation from a No. 2 fuel oil spilt on subsurface soil for 30 years, with a result of the oil remaining in the first $20 \mathrm{~cm}$ of the soil surface and only partial degradation of the alkane fraction had occurred. Wang et al., (1998), showed that a 25-year-old 
crude spill found just beneath the soil surface, at 10-40 cm, showed little degradation. Lundegard \& Johnson (2006) showed that hydrocarbons had a half-life of over 400 years and a zero-order attenuation rate constant of $1.5 \times 10^{-3} \mathrm{a}^{-1}$. McCoy et al. (2015) estimated NAPL biodegradation at a disused refinery using $\mathrm{CO}_{2}$ traps and found average rates of biodegradation to be $6.3 \times 10^{-3} \mathrm{a}^{-1}$ and the half-life was 108 years, which highlight oil persistence in the subsurface. As heavy hydrocarbons are refractory to biodegradation, their persistence in the subsurface environment will be higher.

\subsection{Fate and Sources of Municipal Solid Wastes}

Poor waste management strategies industries, urbanisation, technology, and other human anthropogenic activities result in waste that causes environmental pollution (Rajaganapathyet al., 2011). Some contamination sources include uncontrolled in situ burning, lack of waste segregation, inadequate waste containment, surface runoff, dumpsites close to residential area and waterway, lack of knowledge on waste disposal, spills during transport (Shayley et al., 2009; Stavrianou, 2007; Worksafe, 2005). Shayley et al. (2009) showed that the fate and toxicity of pollutants depend on its source, target, and leachability to the environment. Contaminants affect humans through inhalation, ingestion, dermal, or inhalation. Stavrianou (2007) showed that contaminant toxic properties, concentration, and rate of exposure determine its adverse effect. Contaminants in runoffs pose a danger to species that depend on soil or water contaminated by this runoff. Shayley et al. (2009) showed that soil permeability, mineralogy, the potential of hydrogen $(\mathrm{PH})$, moisture, temperature, porosity, and organic matter could intensify the fate of contaminants. Certain elements that biodegrade might mitigate the toxicity of waste or cause a synergistic effect with toxic waste. Obodai et al., (2011), Aderinola et al.,(2009) and Ene et al., (2009) revealed that toxic heavy metal, which is soluble or suspended in water, could settle to the basal zone to bond with sediment or other biotas.

\subsection{The fate of Heavy Metals in the Environment}

Over the years, the fate of heavy metals in the environment discussed the cycle they undergo, which Brady et al. (1994) gave a conceptual cycle of metals in the report as shown in Figure 2. Natural sources of heavy metals include volcanic eruptions, sea-salt sprays, forest fires, rock weathering, biogenic sources, and wind-borne soil particles. In Herawatiet al. (2000), these heavy metals cause serious health problems to people and other mammals. Similarly, He et al. (2005) stated that anthropogenic sources of heavy metals add more to environmental pollution, like lead from car exhaust, arsenic, copper and zinc from smelting, arsenic from insecticides, and burning of fossil fuels which release vanadium, mercury, selenium, nickel, and tin.

Soils are the highest sinks for heavy metals released into the environment by earlier stated anthropogenic activities. Most heavy metals concentration last long after release to the environment as they are not degradable and do not undergo chemical or microbial degradation (Athar and Vohora, 2001; Lepp, 2012). Heavy metals transported by runoff from industries, municipalities, and urban areas accumulate in the soil and sediments of water bodies (Musilovaet al., 2016). Humans suffer health problems as the concentrations of heavy metals increase in the food chain, and some of the health implications are highlighted in Table 1. (Lee et al., 2002; García-Niño and Pedraza-Chaverrí, 2014). Particulate matters are released into the air through natural processes like volcanic eruptions, dust storms, soil erosion, and rock weathering, while anthropogenic activities are more transport and industrial and related (Soleimani et al., 2018). Particulate matters can lead to skin and eye irritation, respiratory infections, premature mortality, and cardiovascular diseases, the formation of acid rain, deterioration of infrastructure, corrosion, eutrophication, and haze (Herawatiet al., 2000). 


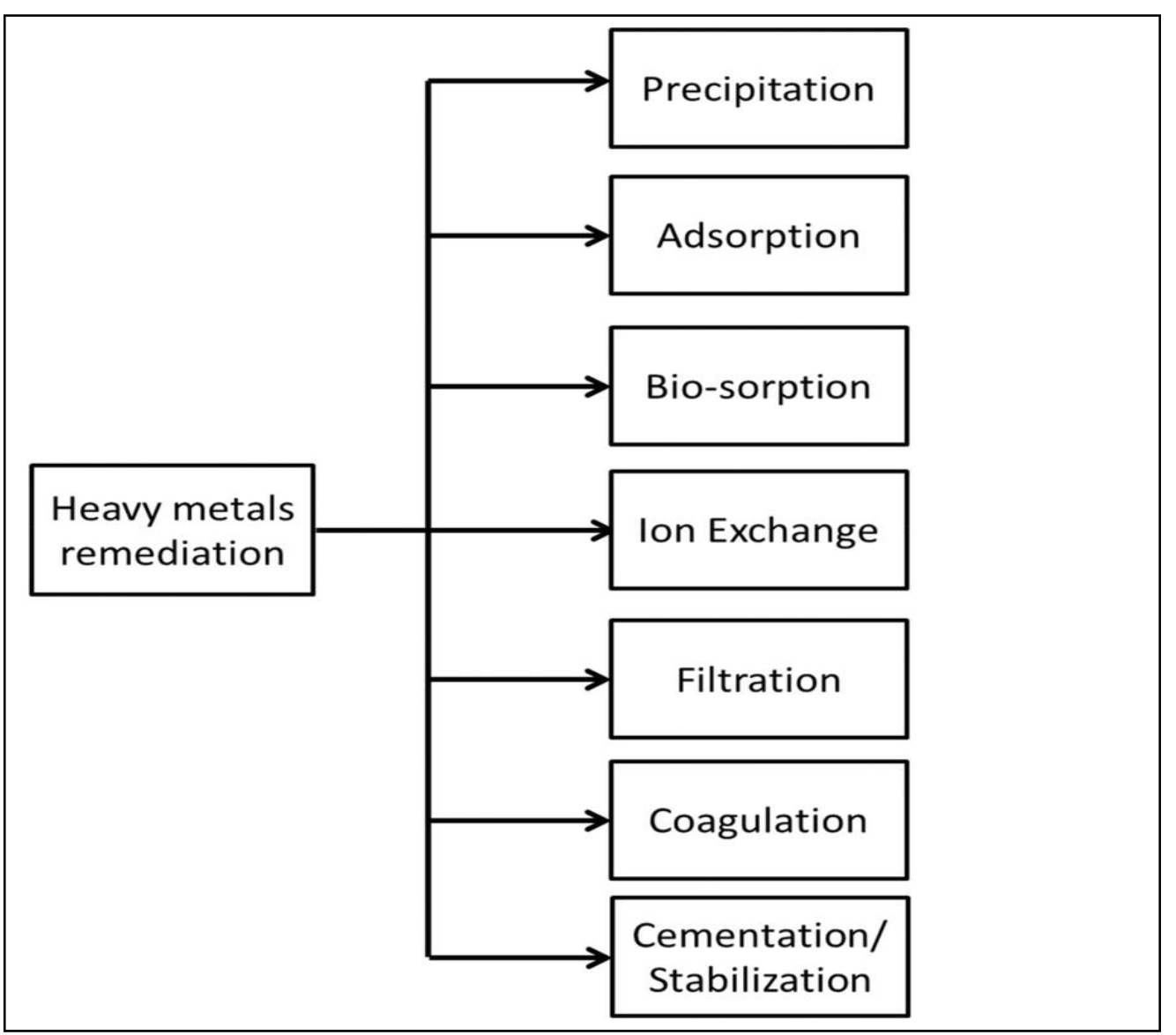

Figure 2: Heavy Metal Sources and their cycle in the Environment (Brady et al., 1994)

Heavy metals like $\mathrm{Cu}, \mathrm{Cd}, \mathrm{Pb}, \mathrm{Cr}, \mathrm{Mn}, \mathrm{Ni}, \mathrm{V}, \mathrm{Zn}, \mathrm{Na}, \mathrm{K}, \mathrm{Ca}, \mathrm{Ti}, \mathrm{Al}, \mathrm{Mg}$, Feoriginate from traffic, industrial areas, and natural sources, (Ventura et al., 2017; Soleimani et al., 2018).

Table1: Heavy metals and their health impacts (García-Niño and Pedraza-Chaverrí, 2014)

\begin{tabular}{|c|c|c|c|c|c|c|}
\hline Health Impact & As & $\mathrm{Cd}$ & $\mathrm{Cr}$ & $\mathrm{Pb}$ & $\mathrm{Hg}$ & $\mathrm{Cu}$ \\
\hline Skin & $\mathrm{X}$ & & $\mathrm{X}$ & & & \\
\hline Lungs & $\mathrm{X}$ & $\mathrm{X}$ & $\mathrm{X}$ & $\mathrm{X}$ & $\mathrm{X}$ & $\mathrm{X}$ \\
\hline Kidneys & $\mathrm{X}$ & $\mathrm{X}$ & $\mathrm{X}$ & $\mathrm{X}$ & $\mathrm{X}$ & $\mathrm{X}$ \\
\hline Liver & $\mathrm{X}$ & $\mathrm{X}$ & $\mathrm{X}$ & $\mathrm{X}$ & $\mathrm{X}$ & $\mathrm{X}$ \\
\hline Brain & $\mathrm{X}$ & $\mathrm{X}$ & $\mathrm{X}$ & $\mathrm{X}$ & $\mathrm{X}$ & $\mathrm{X}$ \\
\hline Pancreas & & & $\mathrm{X}$ & & & \\
\hline Gastrointestinal & & & $\mathrm{X}$ & & & $\mathrm{X}$ \\
\hline Reproductive & & & $\mathrm{X}$ & $\mathrm{X}$ & $\mathrm{X}$ & \\
\hline Immunological & $\mathrm{X}$ & $\mathrm{X}$ & & $\mathrm{X}$ & $\mathrm{X}$ & $\mathrm{X}$ \\
\hline Cardiovascular & $\mathrm{X}$ & $\mathrm{X}$ & & $\mathrm{X}$ & $\mathrm{X}$ & \\
\hline Endocrine & $\mathrm{X}$ & & & & $\mathrm{X}$ & \\
\hline Haematological & & & & $\mathrm{X}$ & & $\mathrm{X}$ \\
\hline Bones & & $\mathrm{X}$ & & $\mathrm{X}$ & & \\
\hline Metabolic & $\mathrm{X}$ & & & & & \\
\hline Testes & & $\mathrm{X}$ & $\mathrm{X}$ & & & \\
\hline Spleen & & & & $\mathrm{X}$ & & \\
\hline Cornea & & & & & & $\mathrm{X}$ \\
\hline
\end{tabular}

Yusuf et al. (2015) discussed techniques for removal of heavy metals from the various environmental matrix (Figure 3). For precipitation, the common alkaline reagents used for sequential recovery of minerals resources from AMD are limestone $\left(\mathrm{CaCO}_{3}\right),(\mathrm{NaOH})$ caustic soda, soda ash $\left(\mathrm{Na}_{2} \mathrm{CO}_{3}\right),(\mathrm{CaO})$, slaked lime, $\left(\mathrm{Ca}(\mathrm{OH})_{2}\right)$ quicklime, and magnesium hydroxide $\left(\mathrm{Mg}(\mathrm{OH})_{2}\right)$ (Masindi et al., 2016). Treatment cost lessens, as some minerals are recovered and sold to metallurgical industries (Nleya et al., 2016). Adsorption is only feasible for very dilute solutions as the adsorbent gets saturated with the adsorbate, is labour-intensive because it requires frequent regeneration, it is not selective in terms of metal attenuation, and is not ideal for extensive metal remediation (Masindi et al., 2016). Ion Exchange uses natural and synthetic clays, synthetic resins, and zeolites 
for removal and attenuation of metals from wastewater (Simate and Ndlovu, 2014; Nleya et al., 2016). Biosorption uses biological materials to remove pollutants from water systems, and it entails the absorption, adsorption, ion exchange, surface complexation, and precipitation. However, further pollutant removal is limited when the concentration of the feed solution is very high as the process reaches a breakthrough (Silvas et al., 2011). Membrane Technologies uses the concentration gradients phenomenon or reverse osmosis and is useful for water that has a high concentration of pollutants. Ultrafiltration, reverse osmosis, microfiltration, nano-filtration, and particle filtration are some membranes that used for mine water treatment (Buzzi et al., 2013; Park et al., 2015; Nleya et al., 2016).

\section{Sources of Heavy metals and their cycling in the soil-water- air organism ecosystem}

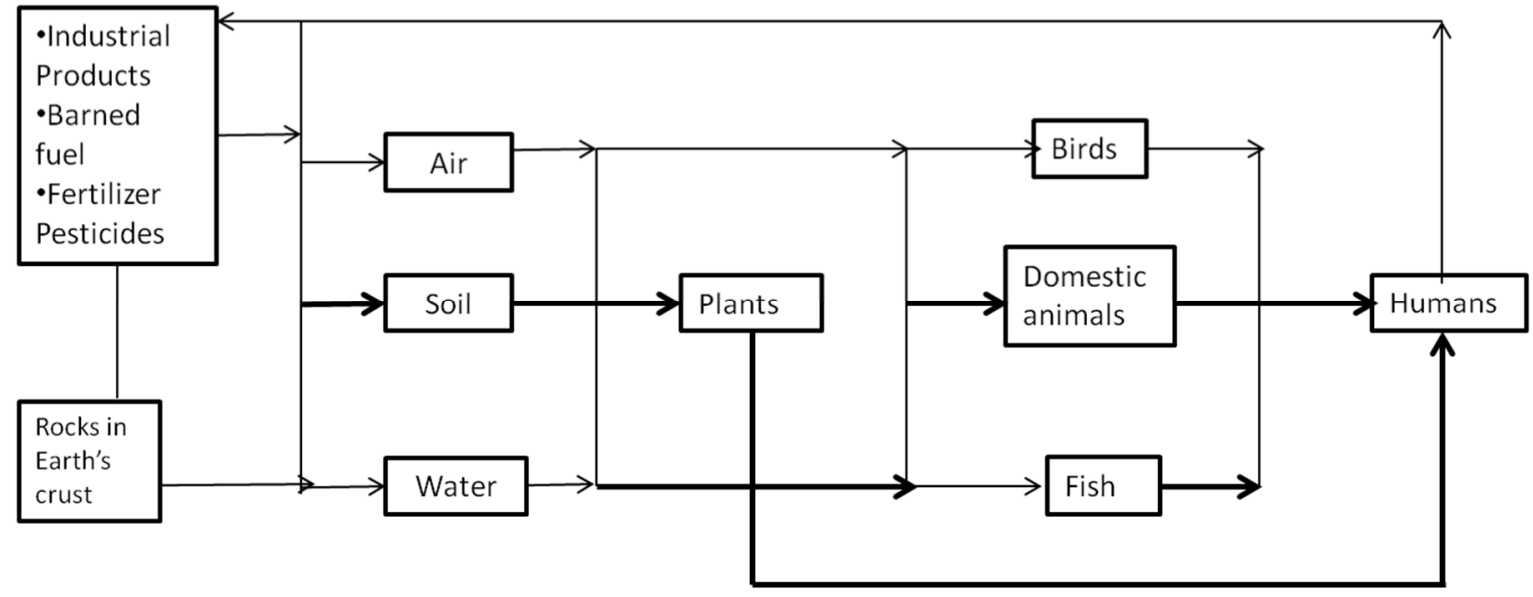

It should be noted that the content of metals in tissue generally builds up from left to right, indicating the vulnerability of humans to heavy metal toxicity

Figure 3: Techniques for the removal of heavy metals (Yusuf et al., 2015)

\subsection{Fate of Plastics}

Littered over the landscape or escaping from landfills, plastic trash makes its way to the sea (Geyer et al., 2017). Different size classes of plastics examined showed less microplastic at the sea surface than expected, given how much plastic litter is estimated to reach the ocean (Eriksen et al., 2014). China, Indonesia, the Philippines, Sri Lanka, and Vietnam - contribute more than half of ocean plastics (Tullo, 2018). The Great Pacific Garbage patch comprising polypropylene and polyethylene is now 16 million $\mathrm{km}^{2}$, about three times the size of France. Fishing nets make up over $46 \%$ of the plastic load, yet microplastics still seem to be missing from the area. An Oceanographer, Laurent Lebreton, and his colleagues predicted that there should be 100 times as much microplastic as they found (Lebreton et al., 2018). Christian Schmidt at the Helmholtz-Centre for Environmental Research and his team combined plastic trash data from 1350 rivers and their watersheds to construct a model of plastic discharges. The researchers estimate that rivers carry as much as 4 million tons of plastic debris to the sea each year. The ten top-ranked rivers transport up to $95 \%$ of the global load into the sea (Schmidt et al., 2017). In a separate study, Lebreton found that two-thirds of the plastic pollution comes from the top 20 rivers, led by China's Yangtze River, India's Ganges River, and a suite of other rivers in Asia (Lebreton et al., 2017). Researchers found multiple contamination hotspots, with one location boasting about 517,000 microplastic particles per square meter - the highest concentration ever measured in freshwater. After winter-time record-breaking floods, the team sampled their sites again, finding a vast reduction in microplastic levels (Hurley et al., 2018). The microplastic pieces size is less than $300 \mu \mathrm{m}$ wide and would pass through the nets used for marine microplastic counting studies; hence, current models may underestimate the concentration of microplastics in the world's oceans. Scientists suspect that wastewater treatment plants could be a significant point source of microplastics in rivers and oceans. The plants are direct recipients of microbeads used in facial scrubs and toothpaste; microfibers washed off of synthetic clothing such as fleece jackets, and tire debris and fragmented plastics from urban runoff. Fionn Murphy of the University of the West of Scotland sampled microplastics at a secondary treatment plant serving a city of 650,000 people. Murphy says the plant releases 65 million microplastics into the River Clyde in Glasgow every day (Murphy et al., 2016).

Chelsea Rochman at the University of Toronto calculates that 8 trillion microbeads per day flow from wastewater treatment plants into aquatic habitats in the United States (Rochmanet al., 2015). Nico Hartline 
estimated that a population of 100,000 people would send $1 \mathrm{~kg}$ of fibres each day to a sewage treatment plant and that synthetic jackets could account for a substantial portion of the fibres observed in sewage influents (Hartline et al., 2016). Farm soils, which are not well studied, could be the most significant environmental reservoir of microplastics, according to Luca Nizzetto (Nizettoet al., 2016). Potential sources of microplastics to soil include inputs from plastic mulch on farm fields, application of sewage sludge, litter, and deposition of air-born particles (Rillig, 2012). Plastic debris soaks up Polychlorinated Biphenyls (PCBs) about 100 times better than naturally occurring materials such as sediment and algae (Engler, 2012). Rochman and her team released virgin polystyrene (PS) pellets into San Diego Bay, once in the water PS absorbed up to 200 times more polycyclic aromatic hydrocarbons (PAHs) than other kinds of plastics. The findings suggest that PS, used in disposable drinking cups, may pose a risk of exposure to PAHs than other plastics do when eaten by wildlife (Rochmanet al., 2013). BBC reported, 'the plastic balls on their own are not toxic, but can absorb toxins lethal to any species that might eat them' (Rochman, 2013).

\section{CURRENT RESEARCH AND REVIEW ON THE FATE OF ORGANIC AND INORGANIC CONTAMINANTS}

Below are some highlighted researches and reviews on the fate of organic and inorganic contaminants in the Niger Delta.

3.1 Case 1: Source Identification of Chemical Contaminants in Environmental Media of a Rural Settlement. Etchie et al., (2011) used Principal Component Analysis (PCA) to identify the source of contaminants such as oil, grease, total petroleum hydrocarbon, chromium $(\mathrm{Cr})$, copper $(\mathrm{Cu})$, cadmium $(\mathrm{Cd})$, nickel $(\mathrm{Ni})$, lead $(\mathrm{Pb})$, and zinc $(\mathrm{Zn}))$ in Ubeji, Niger Delta area. Gravimetry synthetic washing to measure grease, oil, and total petroleum hydrocarbon (TPH), while atomic absorption spectrophotometry detected heavy metals. Significant contamination was detected from a nearby refinery and petrochemical company by grease, oil, $\mathrm{TPH}, \mathrm{Cd}, \mathrm{Cr}$, and $\mathrm{Pb}$.

3.2 Case 2: Environmental Impacts of Oil Exploration and Exploitation in the Niger Delta of Nigeria. Kadafa, Adati Ayuba, (2012) used secondary data to show that although oil is of great benefit to Nigeria, its spillage in the Niger Delta environment has destroyed sources of drinking water, fishing, farmlands, relocation of communities, and the decline of various life forms.

3.3 Case 3: Environmental Implications, Properties, and Attributes of Crude oil in the Oil-producing States of Nigeria. Edokpolor Osazee Ohanmuet al. (2019) used secondary data to highlight the negative impact of crude oil on plant growth, which includes reducing height, stem girth, or total mortality.

3.4 Case 4: Modeling Soil Organic Carbon in Crude Oil Contaminated Soil in the Niger Delta. Nwakwasi et al. (2019) used the panel Data Regression model (PDRM) to analyse crude oil-polluted soil. The result reveals that the soil organic carbon content of the soil at various levels of crude oil pollution varied with time, which is caused by mineralisation and immobilisation processes in the polluted soil environment or because of the presence of the increase carbonaceous substance.

3.5 Case 5: Impact Assessment and Bioremediation of Oil Contaminated Soil: A Case Study of Koko and Ajoki Communities, Niger Delta Nigeria. Imasuen et al. (2014) determined the level of crude oil contamination in the soil and used denitrifying bacteria for twenty-seven days to remediate the soil for agricultural and residential use. Mild pollution was detected, and remediation reduced the organic content, nitrate, phosphorus, and total nitrogen. 3.6 Case 6: Levels of Organochlorine Pesticides in Brackish Water Fish from Niger River, Nigeria. John et al. (2018) investigated levels of organochlorine pesticides (OCPs) in fish samples (Drapane Africana, Mochokus niloticus, Vomer septapinis, Chrysichthys nigrodigitatus, Pristipoma jubelini Pseudotolithus senegalensis, Mugil cephalus, Pseudotolithus elongatus, Sphyraena piscator, and Lutjanus goreensis) from the Delta area of the Niger River. Gas Chromatography (GC) identified the following twenty OCPs: alpha hexachlorocyclohexane $(\alpha$-HCH), beta hexachlorocyclohexane $(\beta-\mathrm{HCH})$, gamma hexachlorocyclohexane $(\gamma-\mathrm{HCH})$, delta hexachlorocyclohexane $(\delta$ $\mathrm{HCH}$ ), dichlorodiphenyldichloroethylene (DDE), dichlorodiphenyltrichloroethane (DDT), endrin, endrin aldehyde, endrin ketone, dieldrin, endosulfan I, endosulfan II, $\gamma$-chlordane, heptachlor, endosulfan sulfate, methoxychlor, $\alpha$-chlordane, heptachlor epoxide, and aldrin from fish samples analysed. The concentration of total OCP compounds amongst the different fish species varied above the World health organisation (WHO) guideline value of $2000 \mu \mathrm{g} / \mathrm{kg}$ fresh weight, and therefore implied potential harmful effects on humans. The contaminated fish makes the river unsuitable for drinking.

3.7 Case 7: Bioremediation of Crude Oil Contaminated Soil using inorganic and organic fertilisers. Ofoegbuet al. (2014) used first-order kinetics model in the remediation of contaminated arable soil at 2, 4, and 6\% crude oil spill, and stimulated with cow dung (CD), palm kernel husk ash (PKHA), nitrogen, phosphorus, potassium (NPK)) applied alone and in combinations (cow dung and inorganic fertiliser); (cow dung and palm kernel husk ash) in a 50:50 ratio in the laboratory for forty days. The results show that amendments with (cow dung \& inorganic fertiliser) have a low half lifetime $(\zeta)$ and a higher biodegradation rate constant $(\mathrm{k})$ and gradually varies with other biostimulants

3.8 Case 8: Environmental Degradation: Key Challenge to Sustainable Economic Development in the Niger Delta. 
Ugoadi (2014) determined that Ogoni indigenes economic and social were affected, and the land may lose its regenerative capacity. The study alerts policymakers to test sustainable development practices from the perspectives of voiceless and powerless indigenous communities that host strategic resource wealth.

3.9 Case 9: Elevated Indoor Volatile Organic Compound Exposure in the Niger Delta Region of Nigeria. Kaléet al. (2018) monitoring volatile organic compounds (VOCs) across different media (water, soil, and air) in Ogoniland at the Niger Delta region, which showed the concentration of benzene and naphthalene that exceed risk benchmark, creating a need for further studies to characterise VOC sources, exposures, and associated health risks in the Niger Delta.

3.10 Case 10: Petroleum Hydrocarbons Contamination of Surface Water and Groundwater in the Niger Delta Region of Nigeria. Aniefioket al. (2018) stated that findings from several studies revealed variable negative impacts of petroleum hydrocarbons toxicity in Nigeria's Niger Delta region, which include environmental pollution, degradation, human health risks, deterioration of cultural heritage items, and socioeconomic problems. This review examines the problems of petroleum hydrocarbons contamination of marine environments associated with unsustainable practices of the petroleum industry in the region. They investigated some of the water quality issues and human health implications of petroleum hydrocarbons contamination of surface-water and groundwater in the oil-producing host communities in Nigeria's Niger Delta region.

3.11 Case 11: Effects of oil spills on fish production in the Niger Delta. Osuagwu and Olaifa (2018) used the Cobb Douglas production function to examine the impact of oil spills into the water body on fish production in the Niger Delta of Nigeria from 1981-2015. The findings were negative and suggested a sustainable approach to oil exploration activities.

3.12 Case 12: Geoenvironmental assessment of hydrocarbon contaminated sites in parts of central swamp depobelt, Eastern Niger delta. Nwankwoala and Mzaga (2017) showed that the effective mitigation of health and socioeconomic impacts of hydrocarbon is a site-specific science and depends on the determination of the extent of spread and prediction of contaminant behaviour. Soil and water samples analysed gave some negative results. They suggested sustainable pollution management strategies by all stakeholders.

3.13 Case 13: Influence of Organic Amendment on Microbial Activities and Growth of Pepper Cultured on Crude Oil Contaminated Niger Delta Soil. Raimi and Sabinus, (2017) showed the effect of Brewers Spent Grains (BSG) on microbial activities and growth of Capsicum annum L cultured in crude oil-contaminated soil. Crude oil increased the acidity and the total organic carbon content while there was a decrease in total nitrogen and available phosphorus levels. BSG promoted the growth of plant height, leaves, flowers, number of branches, fruits, and the leaf area, which shows that plants grow in crude oil contaminated soil if there is an alternative source of nutrients. BSG also enhances the activities of microorganisms and subsequent degradation of hydrocarbons in contaminated soil; hence, it should be a conditioner in contaminated soils to expose nutrients.

3.14 Case 14: Remediation of contaminated lands in the Niger Delta, Nigeria: Prospects and challenges. Zabbeyet al. (2017), stated that remediation attempts in Ogoni land failed because of wrong operational conclusions (oil industry operators concluded that the Niger Delta soil has a layer of clay which makes remediation by enhanced natural attenuation (RENA) suitable for the region as oil percolates on the topsoil) and the use of ineffective remediation techniques. Other challenges include poor regulatory oversight and prolonged conflicts. Case studies showed the effectiveness of bioremediation combined with other technologies for the cleanup of the Niger Delta. 3.15 Case 15: Evaluation of the Effects of Fertilizers and Activated Carbon on Bioremediation of Soil Contaminated with Weathered Crude Oil. Agarry (2018) showed the amount of inorganic NPK fertiliser, organic fertiliser, and activated carbon determines the removal rate of weathered crude oil as they microbial density and activity of the soil, which enhances biodegradation of hydrocarbon and reduces time and cost of bioremediation. 3.16 Case 16: Oil Spillage and Heavy Metals Toxicity Risk in the Niger Delta, Nigeria. Chinedu and Chukwuemeka (2018) used secondary data from governmental and non-governmental organisations to determine that 3.1 million barrels of crude oil containing lead $(\mathrm{Pb})$, nickel $(\mathrm{Ni})$, manganese $(\mathrm{Mn})$, iron $(\mathrm{Fe})$, copper $(\mathrm{Cu})$, zinc (Zn), cobalt (Co), cadmium (Cd) and chromium (Cr) were spilt from 1976 to 2014 in the Niger Delta. Therefore, the inhabitants of this region may be at risk of heavy metals toxicity.

3.17 Case 17: Trace Metal Contamination Health Risks Assessment and Characteristics of Commelina Africana L. and Psammitic Sandflats in the Niger Delta, Nigeria. Nisakaket al. (2016) investigated and quantified trace metal concentrations in Commelina Africana L. and psammitic sandflats in Niger Delta, Nigeria. The concentrations of trace metals varied with the sample locations, and the levels of $\mathrm{Pb}(0.05$ to $0.08 \mathrm{mg} / \mathrm{kg})$ at all locations were below the permissible level of $0.3 \mathrm{mg} / \mathrm{kg}$. The hazard index and quotient show that the psammitic sandflats might pose a health risk to children.

3.18 Case 18: A case study of Ogoniland, Niger Delta region of Nigeria. Ogwugwa et al. (2018) collected samples from five communities in Ogoniland and found heavy metal concentration in these sampled sites exceeded the maximum limit set by the Standard Organization of Nigeria. From the results, Barium had the highest concentration of heavy metal, which is because of the use of barium sulfate to increase the density oil during drilling operations. Barium present in the environment is of public health concern, and uptake of water-soluble 
Barium may cause a person to experience abdominal cramps, diarrhoea, difficulties in breathing, vomiting, increased or decreased blood pressure, and numbness around the face and muscle weakness.

3.19 Case 19: Biodeterioration of plastics by weevils from an environmental and stored food product perspective. Elijah et al. (2015) tested a comparative biodeterioration of nylon by three species of weevils (Tribolium, Sitophilus, and Oryzaephilus) using three types of plastic types and two substrates (plantain flour and rice) for six weeks. The number of borings or holes was considered as an index of biodeterioration. The number of borings increased from the first week to week $6(\mathrm{P}<0.05)$; the substrate and types of plastic bags used affected plastic degradation $(\mathrm{P}<0.05)$. The order of preference for biodeterioration is thin black $>$ thick transparent $>$ thin transparent plastics, plantain being the preferred substrate.

3.20 Case 20: Evaluation of Solid Waste Generation, Categories, and Disposal Options in Developing Countries: A Case Study of Nigeria. Babeyemi and Dauda (2009) investigated the quantity and rate of solid waste generation in several cities in Nigeria, factors influencing the generation, solid waste types and categories, collection, disposal, reuse and recycling, and environmental problems. The results showed a large generation at a high rate without a corresponding efficient technology to manage the wastes.

3.21 Case 21: An Assessment of the Socioeconomic Impact of Crude Oil Pollution on Aquaculture in Gokana Local Government Area Rivers State, Nigeria (Akankali and Nwafili, 2017). It was established that crude oil pollution has adverse and severe socioeconomic impacts on fish farming and led to increased fish mortality rates, reduced yield, and poor quality of cultured fishes.

3.22 Case 22: Phthalate Ester Plasticizers in the Orogodo River Delta State and Their Potential Health Effects. (Edjereet al., 2015) analysed different phthalates such as diethyl phthalates (DEP), dibutyl phthalate (DBP), dimethyl phthalate (DMP), butyl benzyl phthalate (BBP), di-n-octyl phthalate (DNOP), di-2-ethyl hexyl phthalate (DEHP) in Orogodo River. The highest concentrations of phthalates were DEHP and DBP, consistent with their use in plastic materials and other industrial chemicals. The high concentrations may result from emissions arising from the burnt refuse containing plastic materials and dumping of untreated effluent/solid waste along the stretch of the river. Phthalates in the water samples give cause for health and environmental concern for people living downstream of the river.

\section{EFFECTS OF CONTAMINATION ON THE BIODIVERSITY AND NIGER DELTA ENVIRONMENT}

Crude oil, a mixture of many thousands of organic compounds, can vary in composition from one source to another. Therefore, it suggests that the effects of the crude oil spill will vary from source to source. However, details of the potential biological damage will depend on the ecosystem where the spill occurred.

Niger Delta comprises brackish swamp forests, mangrove forests, and rainforests. According to Ibesemin (2010), the degree of oil impact on plant depends on various factors such as the type and amount of oil, the extent of oil coverage, the plant species, the season of the spill and the habitat composition. These impacts range from reduction in population and growth rate or abnormal growth and regrowth to plant mortality. Nwilo et al. (2007) stated that mangrove forests cover 5,000 to $8,580 \mathrm{~km}^{2}$ of land. Janice (2002) mentioned petroleum spills on mangrove halt cellular respiration, starve root of oxygen, and acidify the soils. The increase of toxicity in mangrove soils supporting $R$. racemose attracts Nypa fruticans, which colonise the area. Nypa fruticans shallow root system affects sediment distribution lower in the delta system by destabilising the bank along the waterway. $N$. fruticans impedes navigation and decreases biodiversity. Nigerian Conservation Foundation, (1996) stated that in places $N$. fruticans has invaded, communities are investigating the palm use by the locals. Mangrove forests are a source of wood for local people, and its loss affects not only animals and plants but humans (locals who do not see the economic benefit of petroleum but depend on species vital to subsistence practices).

There are settlements along the banks of the Niger River as it provides water for cleaning, drinking, bathing, and fishing for trading to make a profit and both the dinner table. Settlement of people along the shores of the coasts and rivers, terrestrial and marine habitats are lost, and it changes ecosystems drastically. Molles (2005) stated that shrubs, trees, and the shoreline along the Niger River are vital in maintaining the temperature of the water as temperature change is fatal to some marine species. World Wild Life Fund (2006) stated that the Niger River is home to about 250 fish species, of which 20 are found only in the Niger River. Prevention of temperature rise, oil spills, and pollutions are vital to keeping some of the marine environments. Natural pesticides minimise water contamination from pesticides used in agriculture. The contamination risk can be reduced by enforcing laws and holding oil companies accountable for their actions. Amaize and Emma (2012) stated that biodiversity and productivity of the marine environment could be reduced by holding oil companies accountable, enforcing laws, reducing overfishing, habitat loss, and pollution.

Petroleum hydrocarbons released into the environment are affected by processes that alter the chemical composition of the petroleum hydrocarbon which alters the toxicity. Physical weathering may transform the petroleum hydrocarbon to a form partially available to the organism. The chemical and physical properties of the petroleum hydrocarbon components determine the rate it passes into an organism. The bioavailability and persistence of specific hydrocarbons, the ability of an organism to accumulate and metabolise, The fate of the 
metabolised products, metabolites of the hydrocarbon interphase with the normal metabolic process may alter an organism's chances of survival and reproduction in the environment. The narcotic effects of hydrocarbon on nerve transmission are the primary biological factors in determining the environmental impacts of any release; other factors include photo-degradation and photo-activation. Birds and mammals are vulnerable to oil spills when their habitats become contaminated, and this may reduce reproductive rates, survival and physiological impairment (Briggs et al., 1996). In water, oil film floating on the water surface prevents natural aeration and leads to death of freshwater or marine life and on land lead to retardation of vegetation growth, cause the soil infertility for an extended period (Ukoli, 2005). Ukoli, 2005 in his study made a summary of some significant pollutants from the oil industry released into the environment as follows:

1. Exploration and Production activities include Drilling Muds, Cuttings, Oil and Greases, Salinity, Sulphides, Turbidity, Suspended Solids, Temperature, pH, Heavy metals, Biological Oxygen Demand and COD.

2. Petroleum refining activities include; Oil \& Greases, BOD, COD, Phenol, Cyanide, Sulphide, Suspended solids, Toxic Additives, Hydrocarbons and Total Suspended Solids.

Effects can be either direct damage of a resource or the ability of the environment to support a resource; an effect is over when complete recovery has taken place. To quantify the effects and recovery is difficult; damage to a small area containing highly valued resources can be of greater significance than damage to a much larger area devoid of valued resources. The US DOE has reported that the Niger Delta area has experienced 4,000 oil spills incidences since 1960. These spills result in the loss of mangrove trees to high toxicity levels of the petrochemicals in the environment. The spills have also had adverse effects on the marine habitat which has become contaminated. These splits pose an enormous human health risk from the consumption of contaminated seafood (Twumasi and Merem 2006). The environmental problems of the Niger Delta resulting in generally land resource degradation, renewable resource degradation and environmental pollution, agricultural land degradation, fisheries depletion, deforestation, biodiversity loss, oil pollution, gas flaring and mangrove degradation.

Friends of the Earth (2004) revealed that gas flares release poisonous chemical including sulfur dioxide, a volatile organic compound like benzene, nitrogen dioxides, toluene, xylene, and hydrogen sulfide, benzopyrene and dioxins which can aggravate asthma, chronic bronchitis, cause breathing difficulties and pain, leukaemia, other blood-related diseases, and cancer. Gas flares lack protection for villagers as it causes acid rain which corrodes their homes and other structures. In 2004, the Agency of toxic substances and disease registry stated that some people use asbestos in construction, which repels acid rain. Bronwen Manby (1999) noted that asbestos causes pleural and peritoneal mesothelioma, and asbestosis, and lung cancer. Bronwen Manby (1999) stated that older flares coat the land and communities with soot and damage adjacent vegetation because of heat. Gas flaring violates the constitutional right to life and dignity, and a Nigerian law court ruled that flaring cannot lawfully continue as it is wasteful and damaging. Radio Netherlands Worldwide (2011) and Bloomberg (2011) stated that Shell had not ceased gas flaring.

\section{CONCLUSIONS AND FUTURE PERSPECTIVES}

Research on the fate and transport of heavy hydrocarbons should include understanding heavy hydrocarbon biodegradation, which assists with effective remediation strategies, provide a basis for establishing remediation end-points and help detect whether heavy hydrocarbons are a vital source of metabolic intermediates that become mobile in groundwater or change the risk profile of contaminated soils. Improved analytical capabilities and composition of heavy hydrocarbon will contribute to characterising degradation intermediates and develop realistic physical and chemical properties for this complex fraction. These data can form an overall biodegradation route and bioavailability for heavy hydrocarbons. All stakeholders should be committed to safe waste disposal by providing treatment and recycling facilities, sensitisation of population, and effective legislation. Oil exploration cause harm to the environment. Therefore, oil corporations activities should be monitored. For effective monitoring, funds and qualified human resources must be available. Furthermmore, regulatory bodies should review fines and licenses of oil companies to ensure compliance with legislation.

\section{Acknowledgement}

The authors acknowledged the authors of the research papers and other resources used in this review.

\section{References}

Abbasian, F., Lockington, R., Mallavarapu, M., Naidu, R. (2015). A comprehensive review of aliphatic hydrocarbon biodegradation by bacteria. Applied Biochemistry and Biotechnology, 176, 670-699, https://doi.org/10. 1007/s12010-015-1603-5

Adekunle, I., Adekunle, A., Akintokun, A.K., Akintokun, P.O., Arowolo, T. (2011). Recycling of organic wastes through composting for land applications: A Nigerian experience. Waste Management Res., Pp 582 - 93.

Aderinola O. J., Clarke, E.O., Olarinmoye, O.M., Kusemiju, V., and Anatekhai, M.A. (2009). Heavy Metals in Surface Water, Sediments, Fish, and Periwinkles of Lagos, Lagoon. American-Eurasian J. Agric. \& Environ. 
Sci., 5(5): 609-617.

Agari, SE (2018). Evaluation of the effects of inorganic and organic fertilisers and activated carbon on bioremediation of soil contaminated with weathered crude oil. J. Appl. Sci. Environ. Manage. Vol. 22(4) 587595. DOI: http://dx.doi.org/10.4314/jasem.v22i4.27.

Agency for Toxic Substances and Disease Registry (2007). Asbestos: health effects, retrieved on 29 May 2018.

Akankali, J. A., and Nwafili, S. A. (2017). An Assessment of the Socioeconomic Impact of Crude Oil Pollution on Aquaculture in Gokana Local Government Area Rivers State, Nigeria. Nigerian Journal of Fisheries and Aquaculture 5(1): $87-94$.

Amaize, Emma. (2012) "Nigeria: Pollution in Niger Delta - Oil Firm, Fish Farmers Fight et al. Vanguard. allafrica.com. Retrieved 10 December 2019.

Anderson (2005): Niger River basin: A Vision for Sustainable Development Pp. 1-131 The World Bank.

Aniefiok E.I, Thomas A.H., Clement O.O., Ekpedeme R.A., Iniemem J.I. (2018). "Petroleum hydrocarbons contamination of surface water and groundwater in the Niger Delta region of Nigeria," Journal of Environment Pollution and Human Health, Vol. 6, No.2: 51-61. Doi.10.12691/jephh.6.2.2.

API, (1972). The Migration of Petroleum Products in Soil and Groundwater: Principles and Countermeasures. American Petroleum Institute, Report, 4149.

Athar M., Vohora S.B. (2001). Heavy Metals and Environment. New Delhi: New Age International (P) Limited

Atlas, RM (1981). Microbial degradation of petroleum hydrocarbons: an environmental perspective. Microbiological Reviews, 45, 180-209.

Ayuba, K. A., Manaf, L.A., Sabrina, A.H., and Sulaiman, W. (2013). Current Status of Municipal Solid Waste Management Practise in FCT Abuja. Research Journal of Environmental and Earth Sciences, 5(6): 295 - 304.

Babayemi, J. O., Dauda, K. T. (2009). Evaluation of Solid Waste Generation, Categories, and Disposal Options in Developing Countries: A Case Study of Nigeria. J. Appl. Sci. Environ. Manage. Vol. 13(3) 83 - 88

Baird J (26 July 2010). "Oil's Shame in Africa." Newsweek: 27.

Braddock, J.F., Lindstrom, J.E. \& Prince, R.C. (2003). Weathering of a subarctic oil spill over 25 years: the Caribou-Poker Creeks Research Watershed experiment. Cold Regions Science and Technology, 36, 11-23, https://doi.org/ 10.1016/S0165-232X(02)00076-9

Brady D., Stoll A.D., Starke L., Duncan J.R.. (1994). Bioaccumulation of metal cations by Saccharomyces cerevisiae. Applied Microbiology and Biotechnology. 41:149-154

Briggs, K.T., Yoshida, S.H. and Gershwin, M.E. (1996). The Influence of Petrochemicals and Stress on the Immune System of Seabirds. Regulatory Toxicology and Pharmacology, 23:145-155.

Bronwen Manby (1999): The Price of OilHuman Rights Watch. Retrieved 9 November 2017

Brost, E.J. \& DeVaull, G.E. (2000). Non-aqueous phase liquid (NAPL) mobility limits in soil. API Soil and Groundwater Research Bulletin, 9, 1-9.

Buzzi D.C., Viegas L.S., Rodrigues M.A.S., Bernardes A.M., Tenório J.A.S. (2013). Water recovery from acid mine drainage by electrodialysis. Minerals Engineering. 40:82-89

Cerniglia, C.E. \& Sutherland, G.R. (1992). Degradation of polycyclic aromatic hydrocarbons by fungi. In: Timmis, K.N. (ed.) Handbook of Hydrocarbon and Lipid Microbiology. Springer, Berlin, 2079-2110.

Chinedu E., \&Chukwuemeka K. C. (2018). Oil Spillage and Heavy Metals Toxicity Risk in the Niger Delta, Nigeria. Journal of Health \& Pollution Vol. 8, No. 19.

Coulon, F., Whelan, M.J., Paton, G.I., Semple, K.T., Villa, R., Pollard, S.J. (2010). The multimedia fate of petroleum hydrocarbons in the soil: Oil matrix of constructed biopiles. Chemosphere, 81, 1454-1462, https://doi.org/10.1016/j. chemosphere.2010.08.057

Edjere, O., Asibor, I. G., and Otolo, S. E. (2015). Phthalate Ester Plasticizers in Orogodo River Delta State and their Potential Health Effects. International Journal of Environment and Pollution Research Vol.3, No.45, pp.1-8.

Edokpolor O. O. Sunday, P.B., Erhunmwuse, O., and Osayuwame, O.O. (2019) Environmental implications, properties, and attributes of crude oil in the oil-producing states of Nigeria. Ecologia Vol. 9 (1): 1-9

Elijah I. O, Dorcas D. B, Diepreye E., and Ekeh N. P. (2015). Biodeterioration of plastics by weevils; an environmental and stored food product perspective. International Journal of Geology, Agriculture and Environmental Sciences Volume 3, Issue 1 Pp 51-55.

Ene A., Boşneagă A., and Georgescu L. (2009). Determination of Heavy Metals in Soils using XRF Technique, University of Galati, Faculty of Sciences, Chemistry Department, 111 Domneasca St, 800201 Galati, Romania pp. 815-820.Environmental Science and Technology, 45, 8741-8747, https://doi.org/10. 1021/es202983k

Engler, R. E. (2012). "The Complex Interaction between Marine Debris and Toxic Chemicals in the Ocean" Environ. Sci. Technol. 46(22): 12302-12315

Environment protection authority Victoria, (2018). Point and nonpoint sources of water pollution. https:/www.epa.vic.gov.au/your-environment/water/protecting-victorias-waters/point-and-nonpointsources-of-water-pollution. 
Eriksen, M., Lebreton, L.C.M., Carson, H.S., Thiel, M., Moore, C.J., Borerro, J.C., Galgani, F., Ryan, P.G., Reisser, J. (2014). "Plastic Pollution in the World's Oceans: More than 5 Trillion Plastic Pieces Weighing over 250,000 Tons Afloat at Sea" PLoS ONE. 9(12): e111913

Essential Action, (2000). Oil For Nothing: Multinational Corporations, Environmental Destruction, Death, and Impunity in the Niger Delta. Retrieved 10 November 2019.

Etchie T.O., Etchie A.T., Adewuyi G.O., (2011). Source identification of chemical contaminants in Environmental media of a rural settlement. Research Journal of Environmental Sciences 5(9): 730-740.

Florida department of environmental protection (2019). Inorganic contaminants. https://floridadep.gov/water/source-drinking/content/inorganic-contaminants.

Francke, H.C. \& Clark, F.E. (1974). Disposal of oil wastes by microbial assimilation. US Atomic Energy Commission, Report, Y-1934.

Friends of the Earth Nigeria, (2004). Gas flaring in Nigeria: A human rights, environmental and economic monstrosity.

Fuggle, R.F. (2004): Africa Environment Outlook Lake Victoria: A Case Study of Complex Interrelationships, Pg. 75-85. United Nations Environment Programme.

Furmann, A., Schimmelmann, A., Brassell, S.C., Mastalerz, M., Picardal, F. (2013). Chemical compound classes supporting microbial methanogenesis in coal. Chemical Geology, 339, 226-241, https://doi.org/10.1016/j.chemgeo. 2012.08.010

García-Niño W.R., Pedraza-Chaverrí J. (2014).Protective effect of curcumin against heavy metals induced liver damage. Food and Chemical Toxicology. 69:182-201

Garrett, R.M., Pickering, I.J., Haith, C.E., Prince, R.C. (1998). Photooxidation of crude oils. Environmental Science and Technology, 32, 3719-3723, https:// doi.org/10.1021/es980201r

Geyer, R., Jambeck, J. R., and Law, K. L. (2017). "Production, use, and the fate of all plastics ever made" Sci. Adv. 3(7): e1700782

Grishchenkov, V.G., Townsend, R.T., McDonald, T.J., Autenrieth, R.L., Bonner, J.S., Boronin, A.M. (2000). Degradation of petroleum hydrocarbons by facultative anaerobic bacteria under aerobic and anaerobic conditions. Process Biochemistry, 35, 889-896, https://doi.org/10.1016/S0032-9592(99)00145-4guardian.ng. Retrieved 2019-04-04. "NGOs want FG to withdraw the order for oil exploitation in Ogoni."

Hartline, N.L., Bruce, N.J., Karba, S.N., Ruff, E.O., Sonar, S.U., Holden, P.A. (2016) "Microfiber Masses Recovered from Conventional Machine Washing of New or Aged Garments" Environ. Sci. Technol. 50(21): $11532-11538$

He Z.L., Yang X.E, Stoffella P.J. (2005). Trace elements in agroecosystems and impacts on the environment. Journal of Trace Elements in Medicine and Biology. 19(2-3):125-140

Herawati N., Suzuki S., Hayashi K., Rivai I.F., Koyama H. (2000). Cadmium, copper, and zinc levels in rice and soil of Japan, Indonesia, and China by soil type. Bulletin of Environmental Contamination and Toxicology. 64:33-39

Huesemann, M.H. (1995). A predictive model for estimating the extent of petroleum hydrocarbon biodegradation in contaminated soils. Environmental Science and Technology, 29, 7-18, https://doi.org/10.1021/es00001a002

Hurley, R., Woodward, J., and Rothwell, J. J. (2018). "Microplastic contamination of river beds significantly reduced by catchment-wide flooding" Nat. Geosci. 11: 251-257

Ibemesim, R.I. (2010). Effect of salinity and Wytch farm crude oil on Paspalum conjugatum, Journal of Biological Sciences 10(2): 122-130.

Imaseun OI, Galeasi DT, Omorogieva OM (2014) Impact assessment and bioremediation of oil-contaminated soil: A case study of Koko and Ajoki communities, Niger Delta Nigeria. J. Appl. Sci. Environ. Manage. Vol. 18(1) 55-60. http://dx.doi.org/10.43i4/jasem.v1811.8.

Jalil, A. (2010). Sustainable development in Malaysia: A case study on household waste management. Sustainable Development, 3(3): 91 - 102.

Janice Limson, (2002: Indigenous Plants to the Rescue Environmental remediation in Nigerian oil regions Science in Africa, retrieved on 21 October 2019.

John P. U, Osibanjo O., and Joshua O.B. (2018). Levels of organochlorine pesticides in brackish water fish from Niger River, Nigeria. Hindawi Journal of Environmental and Public Health. Article ID 2658306, nine pages https://doi.org/10.115/2018/2658306.

Kadafa, Adati Ayuba, (2012). Environmental impacts of oil exploration and exploitation in the Niger Delta of Nigeria. Global journal of science frontier research environment and earth sciences. Vol. 12 issue 3 version 1.0

Kale Z. K. (2018). Elevated indoor volatile organic compound exposure in the Niger Delta region of Nigeria. International Journal of Environmental Research and Public Health, 15, 1939; doi.103390/ijerph 15091939.

Keller, K.M. \& Simmons, C.S. (2005). The influence of selected liquid and soil properties on the propagation of 
spills over the flat permeable surface. Pacific Northwest National Laboratory, Washington, Report, PNNL15058.

Kim, S., Stanford, L.A., Rodgers, R.P., Marshall, A.G., Walters, C.C., Qian, K., Wenger, L.M., and Mankiewicz, P. (2005). Microbial alteration of the acidic and neutral polar NSO compounds revealed by Fourier transform ion cyclotron resonance mass spectrometry. Organic Geochemistry, 36, 1117-1134, https://oi.org/10. 1016/j.orggeochem.2005.03.010

Kincannon, CB (1972). Oily waste disposal by soil cultivation process. US Environmental Protection Agency, Washington, DC, Report, EPA-R2-72110.

Kola-Olusanya, A. (2012). Impact of Municipal Solid Wastes on Underground Water Sources in Nigeria. European Scientific Journal, 8(11): 1- 19.

Leahy, J.G. \& Colwell, R.R. (1990). Microbial degradation of hydrocarbons in the environment. Microbiological Reviews, 54, 305-315.

Lebreton, L., Slat, B., Ferrari, F., Sainte-Rose, B., Aitken, J., Marthouse, R., Hajbane, S., Cunsolo, S., Schwarz, A., Levivier, A., Noble, K., Debeljak, P., Maral, H., Schoeneich-Argent, R., Brambini, R., and Reisser, J. (2018). Evidence that the Great Pacific Garbage Patch is rapidly accumulating plastic. Sci Rep. 8(1): 4666

Lebreton, L.C. M., Zwet, J., Damsteeg, J-W., Slat, B., Andrady, A. and Reisser, J. (2017). "River plastic emissions to the world's oceans" Nat. Commun. 8:15611

Lee G., Bigham J.M., Faure G. (2002). Removal of trace metals by coprecipitation with Fe, Al, and Mn from natural waters contaminated with acid mine drainage in the Ducktown Mining District, Tennessee. Applied Geochemistry. 17(5):569-581

Lee, R.F. (2003). Photooxidation and photo-toxicity of crude and refined oils. Spill Science and Technology Bulletin, 8, 157-162, https://doi.org/10.1016/ S1353-2561(03)00015-X

Lepp N.W. (2012). Effect of heavy metal pollution on plants. Metals in the Environment, Pollution Monitoring Series, Applied Science Publishers. Department of Biology. Liverpool, United Kingdom: Liverpool Polytechnic; 2

Loehr, R.C., Martin, J.H. \& Neuhauser, E.F. (1992). Land treatment of an aged oily sludge - organic loss and change in soil characteristics. Water Research, 26, 805-815, https://doi.org/10.1016/0043-1354(92)90012-S

Lundegard, P.D. \& Johnson, P.C. (2006). Source zone natural attenuation at petroleum hydrocarbon spill sitesII: application to a former oil field. Ground Water Monitoring and Remediation, 26, 93-106, https://doi.org/10. 1111/j.1745-6592.2006.00115.x

Maki, H., Sasaki, T. \& Harayama, S. (2001). Photooxidation of biodegraded crude oil and toxicity of the photooxidised products. Chemosphere, 44, 1145-1151, https://doi.org/10.1016/S0045-6535(00)00292-7

Masindi V., Gitari M.W., Tutu H. (2016). Passive Remediation of Acid Mine Drainage. LAP Lambert Academic Publishing

McCarty, P.L. \& Ellis, D.E. (2002). Natural attenuation. In: Reible, D. \& Demnerova, K. (eds) Innovative Approaches to the On-Site Assessment and Remediation of Contaminated Sites. Springer, Dordrecht, 141181.

McCoy, K., Zimbron, J., Sale, T., Lyverse, M. (2015). Measurement of natural losses of LNAPL Using CO2 traps. Groundwater, 53, 658-667, https://doi.org/ 10.1111/gwat.12240

McMillen, S.J., Magaw, R.I., Carovillano, R.L. (2001). An application of the Total Petroleum Hydrocarbon Criteria Working Group (TPHCWG) methodology to crude oils and gas condensates. In: McMillen, S.J. (ed.) RiskBased Decision-Making for Assessing of Petroleum Impacts on Exploration and Production Site.Petroleum Environmental Research Forum and the Department of energy, Tulsa, OK, Pp. 58-76

Meslé, M., Dromart, G. \& Oger, P. (2013). Microbial methanogenesis in subsurface oil and coal. Research in Microbiology, 164, 959-972, https:// doi.org/10.1016/j.resmic.2013.07.004

Molles Jr, MC (2005): Ecology Concepts and Applications 3rd Edition, Pg. 93-94. McGraw-Hill Companies, Inc.

Moustafa, G.S., Mahmoud, M.K., Thanaa, A.M., El-sayed, E.A. (2016). An overview of the organic contaminants. SDRP Journal Of Earth Sciences \& Environmental Studies. Vol. 1, Issue 2.

Murphy, F., Ewins, C., Carbonnier, F., and Quinn, B. (2016). "Wastewater Treatment Works (WwTW) as a Source of Microplastics in the Aquatic Environment" Environ. Sci. Technol. 50(11), 5800-5808

Musilova J., Arvay J., Vollmannova A., Toth T., Tomas J. (2016). Environmental contamination by heavy metals in the region with previous mining activity. Bulletin of Environmental Contamination and Toxicology. 97:569-575

New Hampshire Department of environmental services, (2009). Environmental fact sheet. www.des.nh.gov.

Nham, H.T.T., Greskowiak, J., Nodler, K., Rahman, M.A., Spachos, T., Rusteberg, B., Massmann, G., Sauter, M., and Licha, T. (2015). Modelling the transport behaviour of 16 emerging organic contaminants during soil aquifer treatment. Science of the Total Environment, 514, 450-458, https://doi.org/10.1016/j.scitotenv.2015. 01.096

Nigerian Conservation Foundation (1996). .Nipa Palm Utilization Project Retrieved 21 May 2007. Archived 11 
March 2007, at the Wayback MachineConditions in the Niger Delta Shell.com. Retrieved 16 March 2018.

Nizzetto, L., Futter, M., and Langaas, S. (2016). "Are Agricultural Soils Dumps for Microplastics of Urban Origin?" Environ. Sci. Technol. 50(20): 10777-10779

Nleya Y., Simate G.S., Ndlovu S. (2016). Sustainability assessment of the recovery and utilisation of acid from acid mine drainage. Journal of Cleaner Production. 113:17-27

Nsikak U.B, Paul A.E, Omowunmi H.F-A (2016). Trace Metal Contamination Characteristics and Health Risks Assessment of Commelinaafricana L. and Psammitic Sandflats in the Niger Delta, Nigeria. Applied and Environmental Soil Science Volume 2016, Article ID 8178901, 14 pages

Nwakwasi, L.N., Okoro (2019). Modelling soil organic carbon in crude oil contaminated soil in the Niger Delta. European Journal of Engineering Research and Science. Vol. 4, No.3, DOI: http//dx.doi.org/10.24018/ejers.

Nwankwoala HO, Mzaga TM. (2017). Geo-environmental assessment of hydrocarbon contaminated sites in parts of central swamp depobelt, Eastern Niger Delta. Moj Eco Environ. Sci; 2(3): 100-112. Doi:10.15406/mojes.2017.02.00023.

Nwilo, Peter C., and Olusegun T. Badejo (2007: Impacts And Management of Oil Spill Pollution Along the Nigerian Coastal Areas International Federation of Surveyors. Retrieved 20 May 2019.

Obodai E.A. et al. (2011). The concentration of Heavy Metals in two Ghanaian Lagoons. Archive of Applied Science Research, 3(3): 177-187.

Ofoegbu RU, Momoh YOL, Nwogazie IL (2014). Bioremediation of crude oil contaminated soil using organic and inorganic fertilisers. Journal of Pet. Environ. Biotechnol. 6:198. Doi.104172/21577463.1000198.

Ogwugwa V. H., Ogwugwa J., Idowu O. K., Nwadike B. I., Falodun O. I, Fagade O. E. (2018). Heavy metals, risk indices, and its environmental effects: A case study of Ogoniland, Niger Delta region of Nigeria. International Academy of Ecology and Environmental Sciences, 8(3): 172-182

Okeke, P. N. (2014). Impact of Solid Waste on Physico-Chemical Properties of Ferrealsol in Owerri, Nigeria. African Research Review, 8(3): 116 - 122.

Onwughara, I. N., Nnorom, I. C., Kanno, O. C. (2010). Issues of roadside disposal habit of municipal solid waste, environmental impacts, and implementation of sound management practices in the developing country Nigeria. International Journal of Environmental Science and Development, 1(5): 409 - 418.

Osuagwu ES, Olaifa E (2018). Effects of oil spills on fish production in the Niger Delta. PLoS ONE 13(10),eo205114. http://doi.org/10.1371/journal.pone.o205114.

Park S-M, Shin S-Y, Yang J-S, Ji S-W, Baek K (2015). Selective recovery of dissolved metals from mine drainage using electrochemical reactions. Electrochimica Acta. 181, 248-254

phys.org. Retrieved 2019-04-04."In Nigeria's polluted Ogoniland, signs of a cleanup".Pipeline explosion kills at least 200 CNN. Retrieved 29 September 2019.

Pollard, S.J.T., Hough, R.L., Kim, K-H., Bellarby, J., Paton, G., Semple, K.T., Coulon, F. (2008). Fugacity modelling to predict the distribution of organic contaminants in the soil: oil matrix of constructed biopiles. Chemosphere, 71, 1432-1439, https://doi.org/10.1016/j.chemosphere.2007.12.007

Prince, R.C., Garette, R.M., Bare, R.E., Grossman, M.J., Townsend, T., Suflita, J.M., Lee, K., Owens, E.H., Sergy, G.A., Braddock, J.F., Lindstrom, J.E., Lessard, R.R. (2003). The roles of photooxidation and biodegradation in long-term weathering of crude and heavy fuel oils. Spill Science and Technology Bulletin, 8, 145-156, https://doi.org/10.1016/S13532561(03)00017-3

Radio Netherlands Worldwide, (2011). Nigerian farmer helps put Shell in the dock. Retrieved 7 November 2019.

Raimi M. O. and Sabinus C. E. (2017). Influence of organic amendment on microbial activities and growth of pepper cultured on crude oil contaminated Niger Delta soil. International Journal of Economy, Energy, and Environment. Vol. 2, No.4, Pp. 56-76. DOI:10.116481j.ijee.20170204.12.

Rajaganapathy, V., Xavier, F., Sreekumar, D., Mandal, P.K. (2011). Heavy Metal Contamination in Soil, Water, and Fodder and their presence in Livestock and Products: A Review. Journal of Environmental Science and Technology,4:234-249.

Raymond, R. (2013). "Shell and Ogoni People : (s)oil pollution in the Niger Delta". Peace Palace Library. Retrieved 18 December 2019.

Raymond, R.L., Hudson, J.O. \& Jamison, V.W. (1976). Oil degradation in soil. Applied and Environmental Microbiology, 31, 522-535.

Reddy, C.M., Eglinton, T.I., Hounshell, A., White, H.K., Xu, L., Gaines, R.B., and Frysinger, G.S. (2002). The West Falmouth oil spill after thirty years: the persistence of petroleum hydrocarbons in marsh sediments. Environmental Science and Technology, 36, 4754-4760, https://doi.org/10.1021/es020656n

Rillig, M. C. (2012). "Microplastic in Terrestrial Ecosystems and the Soil?" Environ. Sci. Technol. 46(12), 6453-6454

Rochman, C. M. (2013). "Plastics and Priority Pollutants: A Multiple Stressor in Aquatic Habitats" Environ. Sci. Technol. 47(6): 2439-2440

Rochman, C. M., Manzano, C., Hentschel, B.T., Simonich, S.L.M., and Hoh, E. (2013). Polystyrene Plastic: A 
Source and Sink for Polycyclic Aromatic Hydrocarbons in the Marine Environment. Environ. Sci. Technol. 47(24), 13976-13984

Rochman, C. M., Kross, S.M, Armstrong, J.B., Bogan, M.T., Darling, ES, Green, S.J., Smyth, A.R., and Verissimo, D. (2015). Scientific Evidence Supports a Ban on Microbeads Environ. Sci. Technol. 49(18): 10759-10761

Sakai, Y. Maeng, J.H., Tani, Y., Kato, N. (1994). Use of long-chain n-alkanes (C13-C44) by an isolate, Acinetobacter sp. M-1. Bioscience, Biotechnology, and Biochemistry,58,2128-2130, https://doi.org/10.1271/bbb.58.2128

Salanitro, J.P., Dorn, P.B., Huesemann, M.H., Moore, K.O., Rhodes, I.A., Jackson, L.M.R., Vipond, T.E., Western, MM, and Wisniewski, H.L. (1997). Crude oil hydrocarbon bioremediation and soil ecotoxicity assessment. Environmental Science and Technology, 31, 1769-1776, https://doi.org/10.1021/es960793i

Schmidt, C., Krauth, T., and Wagner, S. (2017). Export of Plastic Debris by Rivers into the Sea. Environ. Sci. Technol. 51(21), 12246-12253

Schwarz, K., Gocht, T., and Grathwohl, P. (2011). Transport of polycyclic aromatic hydrocarbons in highly vulnerable karst systems. Environmental pollution, 159, 133-139, https://doi.org/10.1016/j.envpol.2010.09.026

Seo, J-S., Keum, Y-S., Li, QX. (2009). Bacterial degradation of aromatic compounds. International Journal of Environmental Research and Public Health, 6, 278-309, https://doi.org/10.3390/ijerph6010278

Shankar, R., Shim, W.J., An, J.G., Yim, U.H. (2015). A practical review on photooxidation of crude oil: Laboratory lamp setup and factors affecting it. Water Research, 68, 304-315, https://doi.org/10.1016/j.watres. 2014.10.012

Shayley H., McBride M, and Harrison E. (2009). Sources and Impacts of Contaminants in Soils. Cornell Waste Management Institute, .pp.1-6.

Shell International Petroleum Company, Developments in Nigeria (London: March 1995)

Silvas F.P.C., Buzzi D.C., Espinosa D.C.R., Tenório J.A.S. (2011). Biosorption of AMD metals using Rhodococcusopacus. Revista Escola de Minas, 64,487-492

Simate G.S., Ndlovu S. (2014). Acid mine drainage: Challenges and opportunities. Journal of Environmental Chemical Engineering. 2,1785-1803

Singh, S.K. (1998). Solid waste management: An overview of environmental pollution. Environmental Control Journal, 1(3), 50 - 56.

Soleimani M., Amini N., Sadeghian B., Wang D., Fang L. (2018). Heavy metals and their source identification in particulate matter (PM2.5) in Isfahan City, Iran. Journal of Environmental Sciences. In press

Stavrianou, W. (2007). The Western Australian Contaminated Sites Act 2003: The Applicability of Risk Assessment as a basis for the Assessment and Management of Site Contamination, www.awu.edu.au pp. 192.

Strąpoc, D., Picardal, F.W., Turich, C., Schaperdoth, I., Macalady, J.L., Lipp, J.S., Lin, Y-S., Ertefai, T.F., Schubotz, F., Hinrichs, K-U., Mastalerz, M., Schimmelmann, A. (2008). Methane-producing microbial community in a coal bed of the Illinois Basin. Applied and Environmental Microbiology, 74, 2424-2432, https://doi.org/10.1128/aem.02341-07

Tabatabaee, M.S., Assadi, M.A., Heydarian, M., and Sepahi, A.A. (2012). Soil microbial degradation of vacuum residue. Petroleum Science and Technology, 30, 2218-2226, https://doi.org/10.1080/10916466.2010.511389

Throne-Holst, M., Wentzel, A., Ellingsen, T.E., Kotlar, H-K., Zotchev, S.B. (2007). Identification of novel genes involved in long-chain n-alkane degradation by Acinetobacter sp. strain DSM 17874. Applied and Environmental Microbiology, 73, 3327-3332, https://doi.org/10.1128/AEM.00064-07

Tullo, A.H. (2018). "Fighting ocean plastics at the source" Chem. Eng. News. 96(16); available online at https://cenacs.org/materials/polymers/Fighting-ocean-plastics-source/96/i16

Twumasi, Y. and Merem E. (2006). GIS and Remote Sensing Applications in the Assessment of Change within a Coastal Environment in the Niger Delta Region of Nigeria. International Journal of Environmental Research \& Public Health, 3(1):98106

Ugoadi C.D. (2014). Environmental degradation: Key challenge to sustainable economic Dev. In the Niger Delta. Doctoral Thesis Submission. Walden University.

Ukoli, M.K. (2005). Environmental Factors in the Management of the Oil and Gas Industry in Nigeria. www.cenbank.org

Uribe-Alvarez, C., Ayala, M., Peresgasga, L., Naranjo, L., Urbina, H., Vazquez-Duhalt, R. (2011). The first evidence of mineralization of petroleum asphaltenes by a strain of Neosartorya fischeri. Microbial Biotechnology, 4, 663-672, https://doi.org/10.1111/j.1751-7915.2011.00269.x

Van Wezel, A.P., Sijm, DTHM, Seinen, W. \& Opperhuizen, A. (1995). Use of lethal body burdens to indicate species differences in susceptibility to narcotic toxicants. Chemosphere, 31, 3201-3209, https://doi.org/10.1016/0045-6535 (95)00181-7

Ventura, L.M.B, Mateus, V.L, de Almeida, ACSL, Wanderley, K.B., Taira, F.T., Saint'Pierre, T.D., Gioda, A. 
(2017). Chemical composition of fine particles (PM2.5): Water-soluble organic fraction and trace metals. Air Quality, Atmosphere, and Health, 10,845-852

Wang, T., Zhu, D., Zhang, Z., Hong, L., Yang, C. (2002). High molecular weight (C35 +) n-alkanes of Neogene heavily biodegraded oil in the Qianmiqiao region, North China. Chinese Science Bulletin, 47, 1402-1407, https://doi.org/ 10.1360/02tb9309

Wang, Z., Fingas, M., Blenkinsopp, S., Sergy, G., Landriault, M., Sigouin, L., and Lambert, P. (1998). Study of the 25-Year-Old Nipisi Oil Spill: Persistence of Oil Residues and Comparisons between Surface and Subsurface Sediments. Environmental Science \& Technology, 32, 2222-2232, https://doi.org/10. 1021/es971070h

Wetlands International, (2016). Conserving and restoring wetlands in Nigeria's Niger River Delta; A Case Study. https:/www.wetlands.org/casestudy/conserving-and-restoring-wetlands-in-nigerias-niger-river-delta/

Widdel, F. \& Rabus, R. (2001). Anaerobic biodegradation of saturated and aromatic hydrocarbons. Current Opinion in Biotechnology, 12, 259-276, https://doi.org/10.1016/S0958-1669(00)00209-3

Worksafe, V. (2005). Industry Standard Contaminated Construction Sites. EPA Victoria, www.worksafe.vic.gov.au, First Edition. Pp. 1-28.

World Wildlife Fund. (2006). Fishing on the Niger River. Retrieved 10 January 2020, from http://www.panda.org/news_facts/multimedia/video/index.cfm?uNewsID=61121

Shell (2014). Oil pipeline sabotage

Yusuf M., Elfghi F.M., Zaidi S.A., Abdullah E.C., Khan M.A. (2015). Applications of graphene and its derivatives as an adsorbent for heavy metal and dye removal: A systematic and comprehensive overview. RSC Advance. $5,50392-50420$

Zabbey, N., Sam, K., Onyebuchi, A.T. (2017) Remediation of contaminated lands in the Niger Delta, Nigeria: prospects and challenges, Sci Total Environ (2017), https: //dx.doi.org/10.10.1016/j.scitotenv.2017.02.075 